\title{
Ultrastructural Observations on Spinal Ganglion Biopsy in Friedreich's Ataxia: A Preliminary Report
}

\author{
J. LAMARCHE, C. LUNEAU, B. LEMIEUX
}

\begin{abstract}
We report the preliminary study of a dorsal root ganglion obtained at biopsy during a surgical intervention in a patient with Friedreich's ataxia. There was an apparent decrease in the number of large myelinated fibers without necrosis, but with numerous axonal swellings consisting mainly of dense accumulated neurofilaments. Large amounts of lipofuscin were also found as well as some onion bulb formations suggesting a process of axonal atrophy.
\end{abstract}

RÉSUMÉ: Nous rapportons l'étude préliminaire d'un ganglion dorsal de la moelle, obtenu par biopsie lors d'une intervention chirurgicale, chez un patient avec ataxie de Friedreich. Nous avons noté une diminution apparente du nombre des grosses fibres myélinisées, sans nécrose mais avec un grand nombre de gonflements axonaux qui semblaient consister surtout de neurofilaments accumulés de façon dense. Nous avons également trouvé de grandes quantités de lipofuscine, ainsi que des formations en peaux d'oignon, le tout suggérant un processus d'atrophie axonale.

From the Departments of Pathology, Neurosurgery and Pediatrics, Centre Hospitalier Universitaire, Sherbrooke, Quebec.

Reprint Requests for the complete supplement on Friedreich's ataxia (Phase Three, Part Two) to: Prof. Andrè Barbeau, Clinical Research Institute of Montreal, 110 Pine Avenue West, Montreal, Quebec, Canada H2W IR7.
As part of a systematic neuropathological study of Friedreich's Ataxia, we wish to report some preliminary observations on one of four biopsies of spinal ganglion taken from four individual patients during the surgical correction of scoliosis.

Those biopsies were carried out in an attempt to elucidate one hypothesis of an early initial involvement of the spinal ganglion in Friedreich's Ataxia, based on clinical (Geoffroy et al, 1976), electrophysiological (Peyronnard, 1976; McLeod, 1971), biochemical (Spencer et al, 1979), and morphological observations (Dyck and Lais, 1973; Inoue et al, 1979).

The patient is a 17 year old female with typical Friedreich's ataxia diagnosed at the age of 8 , with a rapidly progressive course, necessitating a wheelchair at the age of 12 . Clinical data were previously published and she was classified in the group $1 \mathrm{~A}$ patient [No. 25 (LD)] in the Quebec study (Côtè et al, 1976).

Three years prior to surgery, the progression of dorso-lombar rotoscoliosis has been rapid, evolving from $53^{\circ}$ to $95^{\circ}$ degrees with early secondary cardiopulmonary manifestations, fulfilling the criteria for surgical correction of the Quebec cooperative study as set up by Allard et al, 1980 .

The biopsy of a D7 right spinal ganglion with a small portion of distal and proximal root was performed. The specimen was immediately fixed by immersion in a solution of $2 \%$ glutaraldehyde paraformaldehyde in $0.1 \mathrm{M}$. phosphate buffer at $\mathrm{PH} 7.4$ and processed according to standard techniques. The spinal ganglion was sectioned in three main portions and labelled as distal, mid, and proximal.

Semi-thin section revealed no ap- parent loss of neurons but the large myelinated fibers appeared to be slightly decreased in number as compared to post-mortem control material. Lipofuscin granules were observed in variable amounts and shapes in the cytoplasm of numerous neurons. Occasional swollen neurons probably containing a great quantity of lipofuscin were seen. Although there was slight proliferation of satellite cells around some neurons no neuronal necrosis or formation of nodule of Nageotte was detected. The most striking finding was the presence of numerous axonal swellings (fig. 1) usually close to the nerve cell body and of several concentric arrangements of Schwann cells suggesting the formation of onion bulbs.

Ultrastructural changes included the presence of several large axons without myelin sheaths and others showing thin myelin with concentric arrangements of Schwann cell processes typical of onion bulb (fig. 2). In several neurons, great amounts of lipofuscin, sometimes of unusual lamellar configuration were found. Also, at times, glycogen granules were observed, forming aggregates in the cytoplasm of the nerve cells. (fig. 4). The axonal swelling consisted mainly of dense accumulation of neurofilaments measuring about 10 nm, (fig. 3).

The finding of demyelinated and remyelinated axons with onion bulb formation is in keeping with previous observations in sural nerve biopsy from Friedreich's ataxia subjects suggesting a process of axonal atrophy. The presence of spheroid like structures observed close to parent cell body, probably corresponds to the axonal swelling observed by Hughes et al (1968). These spheroids have been reported in a great variety of experimental and 


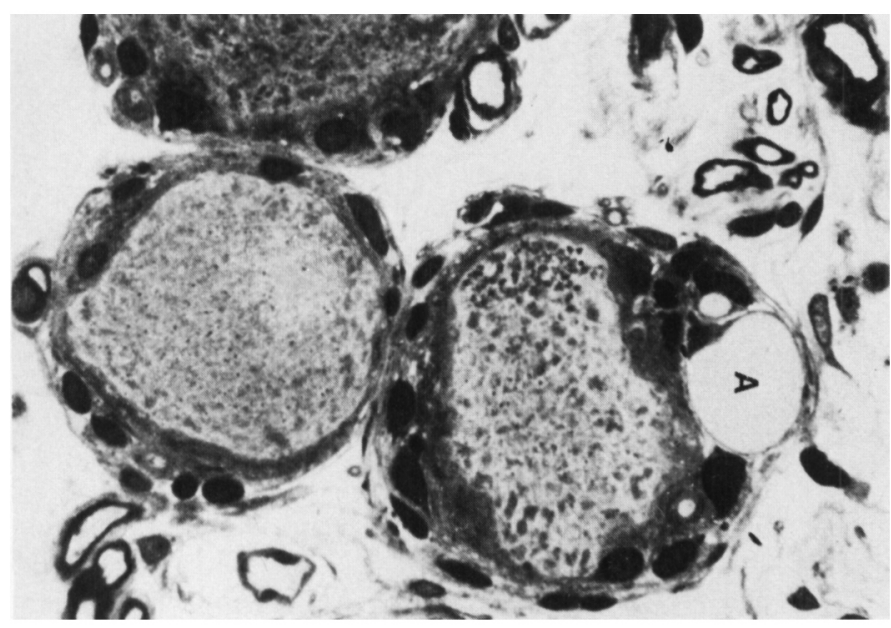

Figure 1 - Central portion of dorsal root ganglion. This micrograph shows one large and one medium sized neuron. Note the axonal swelling (A) and the proliferation of satellite cells in the large neuron. X 700 .

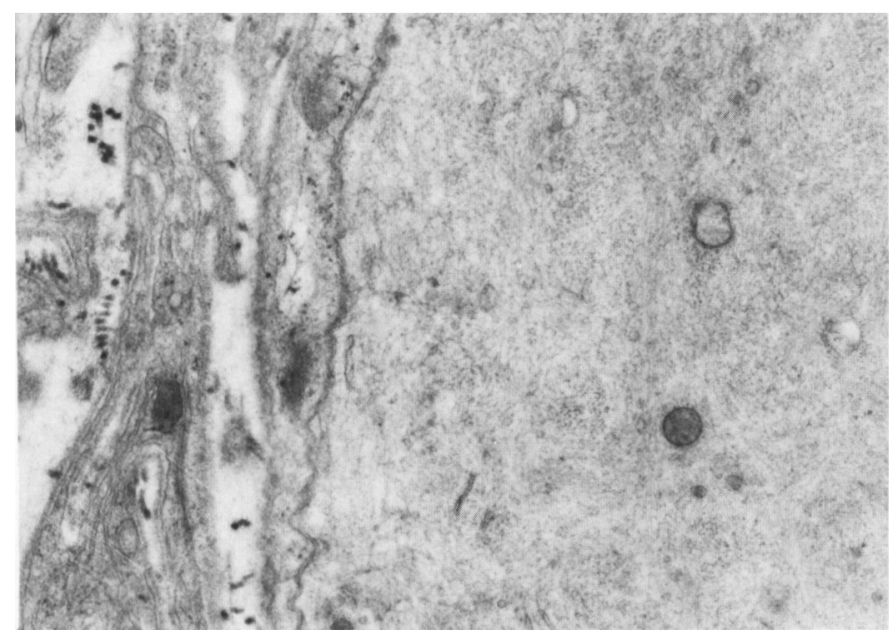

Figure 3 - Swollen axon (spheroid) densely packed with filamentous structure of about $10 \mathrm{~nm}$ diameter. $X 30324$.

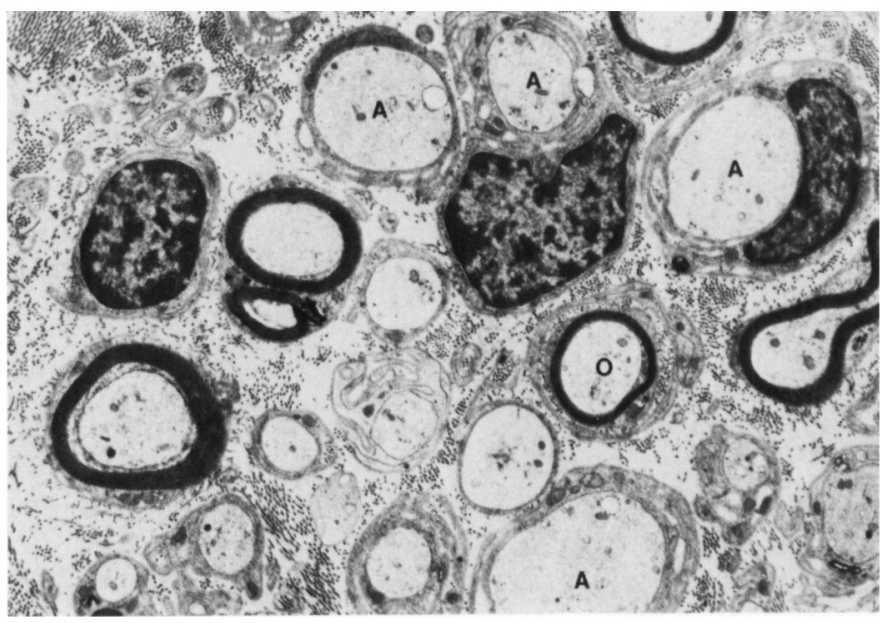

Figure 2 - Mid portion of dorsal root ganglion. Many demyelinated axons (A) of large diameter are present, some with concentric arrangements of , Schwann cell cytoplasm. One onion bulb (0) situated around a central thinly myelinated fiber is observed. X 11172 .

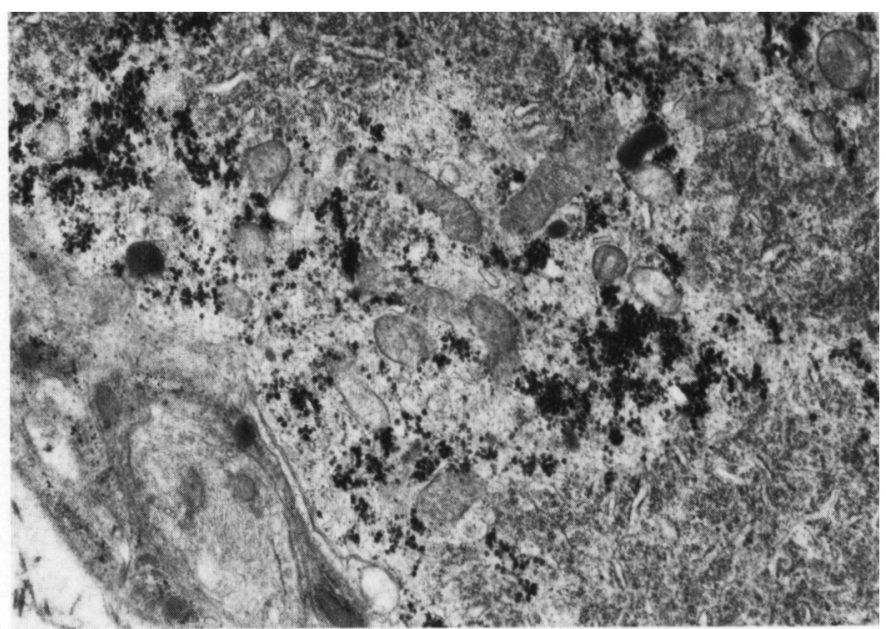

Figure 4 - Dense aggregates of glycogen granules in the cytoplasm of neuron. X 25650 . naturally occurring conditions including Friedreich's ataxia and vitamin E deficiency (Jellinger, 1973; Cavanagh, 1979). Vitamin E deficiency may be associated with spinocerebellar disorders (Elias et al, 1981).

The presence of glycogen in the cytoplasm of neurons may be normal or related to abnormal energy metabolism. The hypothesis suggested by Spencer et al, 1979 of a defect in energy metabolism in polyneuropathy deserves to be studied further by biochemical methods in tissue culture of ganglia.

\section{ACKNOWLEDGEMENTS}

The preliminary studies reported in this paper were supported by a grant from l'Association Canadienne et l'Ataxie de Friedreich.

\section{REFERENCES}

ALlARD, P., DUHAIME, M., RASO, J.V., THIRY, P.S., DROUIN, G., and GEOFFROY, G. (1980). Pathomechanics and Management of Scoliosis in Friedreich's ataxia patients. Can. J. Neurol. Sci, 7: 383388.

CAVANAGH, J.B.: The "dying back" process (1979). A common denominator in many naturally occurring and toxic neuropathies. Arch. Pathol. Lab. Med. 103: 569-664.
CÔTE, M., DAVIGNON, A., PECKODROUIN, K., SOLIGNAC, GEOFFROY, G., LEMIEUX, B., and BARBEAU, A. (1976). Cardiological signs and symptoms in Friedreich's ataxia. Can. J. Neurol. Sci, 3: 319-321.

DYCK, P.J. and LAIS, A.C. (1973). Evidence for segmental demyelination secondary to axonal degeneration in Friedreich's ataxia. In: Kakulas, B. (ed) Clinical Studies in Myology. Int. Congr. Series. K. Amsterdam, Excerpta Medica: 252-263.

ELIAS, E., MULLER, D.P.R., and SCOTT, J. (1981). Association of spino-cerebellar disorders with cystic fibrosis or chronic childhood cholestasis and very low serum vitamin $\mathrm{E}$. The Lancet: 1319-1321. 
GEOFFROY, G., BARBEAU, A., BRETON, G., LEMIEUX, B., AUBE, M., LÉGER, C., and BOUCHARD, J.B. (1976). Clinical description and roentgenologic evaluation of patients with Friedreich's ataxia. Can. J. Neurol. Sci, 3: 279-286.

HUGHES, J.T., BROWNELL, B., and HER WER, R.L. (1968). The peripheral sensory pathway in Friedreich's Ataxia. An examination by light and electron microscopy of the posterior nerve roots, posterior root ganglia and peripheral sensory nerves in cases of Friedreich's ataxia. Brain 91: 803818.

INOUE, K., HIRANO, A., and HASSIN, J.
(1979). Friedreich's ataxia selectively involves the large neurons of the dorsal root ganglia (abstract). Annals of Neurol: 6, 150.

JELLINGER, J. (1973). Neuroaxonal dystrophy: its natural history and related disorders. in: Zimmerman, H.M. (ed). Progress in neuropathology. New York, Grune and Stratton, vol. II: 129-180.

McLEOD, J.G. (1971). An electrophysiological and pathological study of peripheral nerves in Friedreich's ataxia. J. Neurol. Sci. 12: 333-349.

PEYRONNARD, J.M., BOUCHARD, J.P., LAPOINTE, L., LAMONTAGNE, A.,
LEMIEUX, B., and BARBEAU, A. (1976): Nerve conduction studies and electromyography in Friedreich's ataxia. Can. J. Neurol. Sci, 3: 313-317.

SPENCER, P.S., SCHAUMBURG, H.H. (1976). Central-peripheral-distal-axonopathy: The pathology of "dying back" neuropathies. in: Zimmerman, H.M. (ed) Progress in Neuropathology. New York, Grune and Stratton, Vol. 3: 253-295.

SPENCER, P.S., SABRI, M.I., SCHAUMBURG, H.H. and MOORE, C.L. (1979). Does a defect of energy metabolism in the nerve fiber underlie axonal degeneration in polyneuropathies. Ann. Neurol. 5: 501-507. 